\title{
Serum Levels of Novel Biochemical Marker (Irisin) in Relation to the Duration of Type 2 Diabetes \& in Cases of Type 2 diabetes with Coronary Artery Disease in Iraqi Patients Aged (40- 60 year)
}

\author{
Dunia Tahseen Nema Al-Aridhi ${ }^{1}$, Khalid I.H. Allehibi ${ }^{2}$, Zainab A. Razak Al-Sharifi, \\ Muthanna Al Quraishi ${ }^{4}$ \\ ${ }^{1}$ Lecturer / Biomedical Engineering Dept. /College of Engineering / Al-Nahrain University / Baghdad-Iraq, \\ ${ }^{2}$ Consultant Endocrinologist / The Specialized Center for Endocrinology and Diabetes / Baghdad-Iraq, \\ ${ }^{3}$ Assistant prof. / Department of Biochemistry / University of Baghdad / College of Medicine / Baghdad-Iraq, \\ ${ }^{4}$ Consultant interventional Cardiologists / Ibn-albitar Hospital for Cardiac Surgery / Baghdad-Iraq
}

\begin{abstract}
Background: Type 2 diabetes mellitus (T2DM) is a metabolic syndrome that affects a large proportion of the population, if not well controlled; this will lead to serious metabolic problems, including atherosclerosis, predominantly coronary artery disease (CAD).

Irisin is a peptide hormone, secreted mainly by the heart and skeletal muscle. It has a role in converting white adipose tissue to brown adipose tissue. It is one of the novel biochemical markers that link diabetes with CAD.
\end{abstract}

Objective : To explore the relationship between serum Irisin level and duration of diabetes, in cases of presence and absence of CAD, As well as the possibility of using it as a marker for the assessment of the severity of the disease.

Method: One hundred sixty-one volunteers aged [(40-60 year), body mass index $\left.\left(20-25 \mathrm{Kg} / \mathrm{m}^{2}\right)\right]$, with normal blood pressure. They divided into six groups, that distributed as $\left[\left(\mathrm{I}_{\mathrm{a}}=\right.\right.$ control (negative catheterization without DM), $\mathrm{I}_{\mathrm{b}}=$ control (apparently healthy), $\mathrm{II}_{\mathrm{a}}=\mathrm{DM}$ (with negative catheterization) $\mathrm{II}_{\mathrm{b}}=\mathrm{DM}$ (diagnosed by history and clinical examination), $\mathrm{III}_{\mathrm{a}}=\mathrm{CAD}$ (without $\mathrm{DM}$, positive catheterization), $\mathrm{III}_{\mathrm{b}}=\mathrm{CAD}+\mathrm{DM}$ (positive catheterization)]. The diabetic groups with and without CAD had been divided depending on the duration of the diabetic onset into three periods $(<5,5-10$, and $>10$ years). The parameters that measured were FPG, HbA1c and fasting serum (Irisin, lipid profile).

Results: The present findings showed the Means $( \pm$ SD) value of Irisin levels was a significant decrease in $\left(\mathrm{II}_{\mathrm{a}}, \mathrm{II}_{\mathrm{b}}, \mathrm{III}_{\mathrm{a}}, \mathrm{III}_{\mathrm{b}}\right)$ groups as compared with control groups $\left(\mathrm{I}_{\mathrm{a}}, \mathrm{I}_{\mathrm{b}}\right)$. In addition, there is an inverse relationship between serum Irisin and the duration of DM in the total DM groups $\left(\mathrm{II}_{\mathrm{a}}+\mathrm{II}_{\mathrm{b}}\right)$ and the CAD $+\mathrm{DM}$ group $\left(\mathrm{III}_{\mathrm{b}}\right)$. Moreover, higher statistical decrease in mean serum level of Irisin with duration of DM was found in CAD + DM group as compared with the total DM group. Also, there was a significant decrease in mean serum level of HDL-C for $\left(\mathrm{II}_{\mathrm{a}}, \mathrm{II}_{\mathrm{b}}, \mathrm{III}_{\mathrm{a}}, \mathrm{III}_{\mathrm{b}}\right)$ groups than in $\left(\mathrm{I}_{\mathrm{a}}, \mathrm{I}_{\mathrm{b}}\right)$ groups. Besides, there was a significant decrease in the mean of serum HDL level in CAD groups ( $\left.\mathrm{III}_{\mathrm{a}}, \mathrm{III}_{\mathrm{b}}\right)$ than in DM groups $\left(\mathrm{II}_{\mathrm{a}}\right.$, $\left.\mathrm{II}_{\mathrm{b}}\right)$. While the means of FPG level, HbA1c, serum cholesterol level, were significantly elevated in groups $\left(\mathrm{II}_{\mathrm{a}}, \mathrm{II}_{\mathrm{b}}, \mathrm{III}_{\mathrm{b}}\right)$ as compared with $\left(\mathrm{I}_{\mathrm{a}}, \mathrm{I}_{\mathrm{b}}\right)$ groups. Also, there was a significant increase in the mean serum levels of triglyceride, VLDL-C and LDL-C for ( $\left.\mathrm{II}_{\mathrm{a}}, \mathrm{II}_{\mathrm{b}}, \mathrm{III}_{\mathrm{a}}, \mathrm{II}_{\mathrm{b}}\right)$ groups than in the control groups.

Conclusion: Irisin was lower among patients with long-standing diabetes (with or without CAD) as compared to those with short duration of T2DM that can be included as a marker for assessment the severity of diabetes and prediction of CAD.

Keywords: Irisin, duration of T2DM, CAD. 


\section{Introduction}

TYPE 2 Diabetes Mellitus (T2DM) is a heterogeneous syndrome, manifested by abnormalities in carbohydrate and fat metabolism. It is characterized by insulin resistance, a relative deficiency of insulin secretion and abnormal insulin action as a result; abnormal glucose homeostasis ${ }^{(1)}$.

Abnormality of insulin secretion and insulin action at the target tissues associated with a defect in management leads to hyperglycemia. When hyperglycemia persists for prolonged periods, patients can develop various complications, including both microvascular like, nephropathy, retinopathy, and peripheral neuropathy, and macrovascular, e.g., cardiovascular disease (CVD) (2).

In January 2012, Bostrom and colleagues identified a new muscle tissue secreted peptide, which they named Irisin. It is a cleavage product of fibronectin type III domain-containing protein FNDC5 ${ }^{(3)}$.

Irisin containing (112 amino acid), acts as a hormone (glycosylated protein- hormone), that is released from skeletal muscle following exercise. Irisin secreted by the response of peroxisome proliferator-activated receptorgamma co-activator (PGC-1 $\alpha$ ) activation via training ${ }^{(4)}$.

Irisin is mainly produced in the heart, skeletal muscle, kidney, and liver. It is essential to convert white adipose tissue to brown adipose tissue ${ }^{(5)}$.

Irisin affect glucose homeostasis. It had also been regarded as an anti-inflammatory marker, in correlation with diabetes and insulin resistance ${ }^{(6)}$. Circulating Irisin is positively associated with endothelium-dependent vasodilation in diabetic patients without clinical angiopathy, indicating that low level of circulating Irisin tightly related to endothelial dysfunction and could be a marker for atherosclerosis in $\mathrm{T}_{2} \mathrm{DM}^{(7)}$.

\section{Subjects \& Methods}

\section{Subjects}

One hundred sixty-one voluntaries from (The specialized center for endocrinology and diabetes) and (Cardiologic clinics of Ibn- Al-Bitar hospital) were encountered in this study (September 2017 - September 2018). They were divided into six groups, table (1).
Table (1): Groups numbers and distributions

\begin{tabular}{|l|l|l|}
\hline Groups & Criteria & $\begin{array}{l}\text { Voluntaries } \\
\text { NO. }\end{array}$ \\
\hline $\mathbf{I}_{\mathbf{a}}$ & $\begin{array}{l}\text { Control / negative } \\
\text { catheterization without } \\
\text { DM }\end{array}$ & 28 \\
\hline $\mathbf{I}_{\mathbf{b}}$ & $\begin{array}{l}\text { Control /apparently } \\
\text { healthy }\end{array}$ & 25 \\
\hline $\mathbf{I I}_{\mathbf{a}}$ & $\begin{array}{l}\text { DM / with negative } \\
\text { catheterization }\end{array}$ & 30 \\
\hline $\mathbf{I I}_{\mathbf{b}}$ & $\begin{array}{l}\text { DM / diagnosed by } \\
\text { history and clinical } \\
\text { examination }\end{array}$ & 25 \\
\hline $\mathbf{I I I}_{\mathbf{a}}$ & $\begin{array}{l}\text { CAD without } \\
\text { DM / (positive } \\
\text { catheterization) }\end{array}$ & 20 \\
\hline $\mathbf{I I I}_{\mathbf{b}}$ & $\begin{array}{l}\text { CAD + DM / (positive } \\
\text { catheterization) }\end{array}$ & 33 \\
\hline
\end{tabular}

\section{Method}

Two methods have been used:-

Enzyme-linked immunosorbent assay (ELISA) for measuring Irisin (after three months stored in deep freezing $-80^{\circ} \mathrm{C}$ ) in the central health laboratory, using the kit supplied by my biosource/USA.

Enzyme colourimetric methods for measuring FPG, HbA1c, Lipid profile, by a spectrophotometer using kits provided by Human Gesellschaft fur Biochemica and mbHMax- Planck Germany.

Besides [the electrocardiogram (ECG), ECHO, tread mill] were done for the groups $\left(\mathrm{I}_{\mathrm{b}}, \mathrm{II}_{\mathrm{b}}\right)$ while groups $\left(\mathrm{I}_{\mathrm{a}}, \mathrm{II}_{\mathrm{a}}, \mathrm{III}_{\mathrm{a}}, \mathrm{III}_{\mathrm{b}}\right)$ diagnosed by clinical examination of coronary computed tomography angiogram (CCTA), and they undergo catheterization (either diagnostic or therapeutic), this is according to their cardiologist decision (Regardless of search requirements). 


\section{Statistical Analysis}

The statistical package for social sciences version (SPSS-23) has been used. The statistical significance of the difference in mean of a normally distributed quantitative variable was assessed by the analysis of variance (ANOVA) test, and the statistical significance of the difference in mean between all possible pair of groups was assessed by the least standard deviation (LSD) test. P-value $\leq 0.05$ considered being statistically significant.

\section{Results}

There was a significant decrease in means serum levels of Irisin for overall groups when compared with that found in control groups [P-value $=0.003]$. While the results showed no significant difference in mean of Irisin level [between control groups $\left(\mathrm{I}_{\mathrm{a}}\right.$ and $\left.\mathrm{I}_{\mathrm{b}}\right)$, between diabetic groups $\left(\mathrm{II}_{\mathrm{a}}\right.$ and $\left.\mathrm{II}_{\mathrm{b}}\right)$, and among groups $\left(\mathrm{II}_{\mathrm{a}}, \mathrm{II}_{\mathrm{b}}\right.$, $\left.\left.\mathrm{III}_{\mathrm{a}}, \mathrm{III}_{\mathrm{b}}\right)\right]$, table (2), figure (1).

\begin{tabular}{|l|l|l|}
\hline & \multicolumn{2}{|l|}{$\begin{array}{l}\text { Table (2): The difference in means of serum } \\
\text { Irisin }\end{array}$} \\
\hline & $\begin{array}{l}\text { Parameter } \\
\text { Groups }\end{array}$ & $\begin{array}{l}\text { Serum Irisin (ng/ml) } \\
\text { (mean } \pm \text { SD) }\end{array}$ \\
\hline & $\mathrm{I}_{\mathrm{a}}$ & $\begin{array}{l}\text { A } \\
29.341 \pm 16.213\end{array}$ \\
\hline & $\mathrm{I}_{\mathrm{b}}$ & $\begin{array}{l}\text { A } \\
30.149 \pm 16.032\end{array}$ \\
\hline & $\mathrm{II}_{\mathrm{a}}$ & $\begin{array}{l}\text { B } \\
9.014 \pm 2.009\end{array}$ \\
\hline & $\mathrm{II}_{\mathrm{b}}$ & $\begin{array}{l}\text { B } \\
9.675 \pm 1.931\end{array}$ \\
\hline & $\mathrm{II}_{\mathrm{a}}$ & $\begin{array}{l}\text { B } \\
5.777 \pm 0.450\end{array}$ \\
\hline & $\mathrm{III}_{\mathrm{b}}$ & $\begin{array}{l}\text { B } \\
3.728 \pm 1.283\end{array}$ \\
\hline & LSD $^{7.427}$ \\
\hline & $\mathrm{P}_{-}$value & Sig. 0.003 \\
\hline The Letters (A, B, C) are significant at P $\leq 0.05$ \\
\hline
\end{tabular}

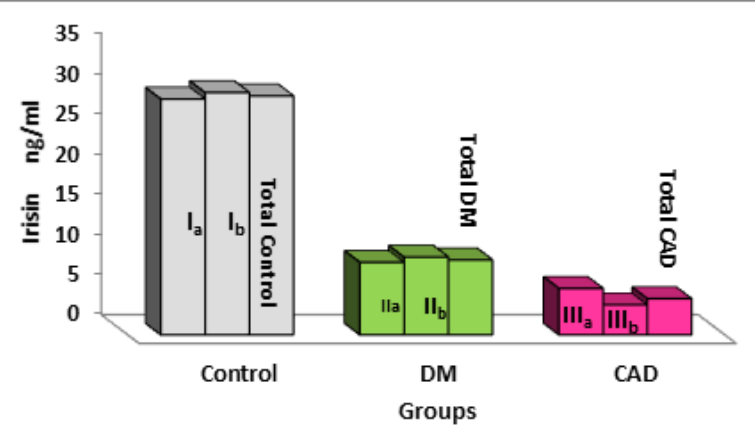

Figure (1): Bar chart showing the difference in mean of serum Irisin

There was an inverse relationship between serum Irisin level and the duration of incidence of T2DM in the [total DM groups $\left(\mathrm{II}_{\mathrm{a}}+\mathrm{II}_{\mathrm{b}}\right)$ and $\mathrm{CAD}+\mathrm{DM}$ group $\left(\mathrm{III}_{\mathrm{b}}\right.$ ], table (3) figure (2).

In the total DM group, the mean serum level of Irisin was [ $(12.347 \pm 0.712 \mathrm{ng} / \mathrm{ml}),(10.922 \pm 1.316 \mathrm{ng} / \mathrm{ml})$ and $(8.295 \pm 1.259 \mathrm{ng} / \mathrm{ml})$ when DM duration $[(<5 \mathrm{y}),(5-$ $10 \mathrm{y})$ and $(>10 \mathrm{y})$, respectively], There were significantly decreased in mean of serum Irisin levels when the duration of DM was increased ( $\mathrm{LSD}=0.954$ ) [P- value (0.0018)].

In the $\left(\mathrm{III}_{\mathrm{b}}\right)$ group, the mean serum level of Irisin was $[(4.9527 \pm 0.3178 \mathrm{ng} / \mathrm{ml}),(4.0562 \pm 0.5580 \mathrm{ng} / \mathrm{ml})$ and $(2.4649 \pm 0.9561 \mathrm{ng} / \mathrm{ml})]$ when DM duration $[(<5 \mathrm{y})$, $(5-10 y)$ and $(>10 y)$, respectively], The results show significant difference in mean of serum Irisin level between duration $(<5 \mathrm{y}, 5-10 \mathrm{y})$ compared $(>10 \mathrm{y})$ (LSD $>1.07)$. While there was no significant difference in mean of serum Irisin level between duration $(<5 y)$ and (5-10y). (LSD < 1.07), [P-value (0.0026)].

The highest statistically difference in mean serum levels of Irisin with a duration of DM was found in ( $\left.\mathrm{III}_{\mathrm{b}}\right)$ group as compared with (total DM) groups, [P- value $(0.00031,0.00046,0.00053)]$ for duration $[(<5 y),(5-$ $10 \mathrm{y})$ and $(>10 \mathrm{y})$, respectively], as shown in table (3), figure (2). 
Table (3): The difference in mean between serum levels of Irisin and the duration
of T2DM in Total DM group \& in CAD + DM group

\begin{tabular}{|l|l|l|l|l|}
\hline $\begin{array}{l}\text { Group } \\
\text { Duration (year) }\end{array}$ & $\begin{array}{l}\text { Total DM } \\
(\text { IIa }+ \text { IIb) } \\
(\text { mean } \pm \text { SD) }\end{array}$ & $\begin{array}{l}\text { CAD+DM } \\
\text { (IIIb) } \\
(\text { mean } \pm \text { SD) }\end{array}$ & LSD & P-value \\
\hline$<5$ & $\begin{array}{l}\text { A,a } \\
12.347 \pm 0.712\end{array}$ & $\begin{array}{l}\text { A,b } \\
4.9527 \pm 0.3178\end{array}$ & 3.281 & 0.00031 \\
\hline $5-10$ & $\begin{array}{l}\text { B,a } \\
10.922 \pm 1.316\end{array}$ & $\begin{array}{l}\text { A,b } \\
4.0562 \pm 0.5580\end{array}$ & 2.185 & 0.00046 \\
\hline$>10$ & $\begin{array}{l}\text { C,a } \\
8.295 \pm 1.259\end{array}$ & $\begin{array}{l}\text { B,b } \\
2.4649 \pm 0.9561\end{array}$ & 2.966 & 0.00053 \\
\hline LSD & 0.954 & 1.07 & 0.0026 & \\
\hline & P-value & 0.0018 & \\
\hline
\end{tabular}

The Letters (A, B, C) are significant at $\mathrm{P} \leq 0.05$ (comparison in the same group)

The Letters $(\mathrm{a}, \mathrm{b})$ are significant at $\mathrm{P} \leq 0.05$ (comparison between Total DM group and CAD + DM group)

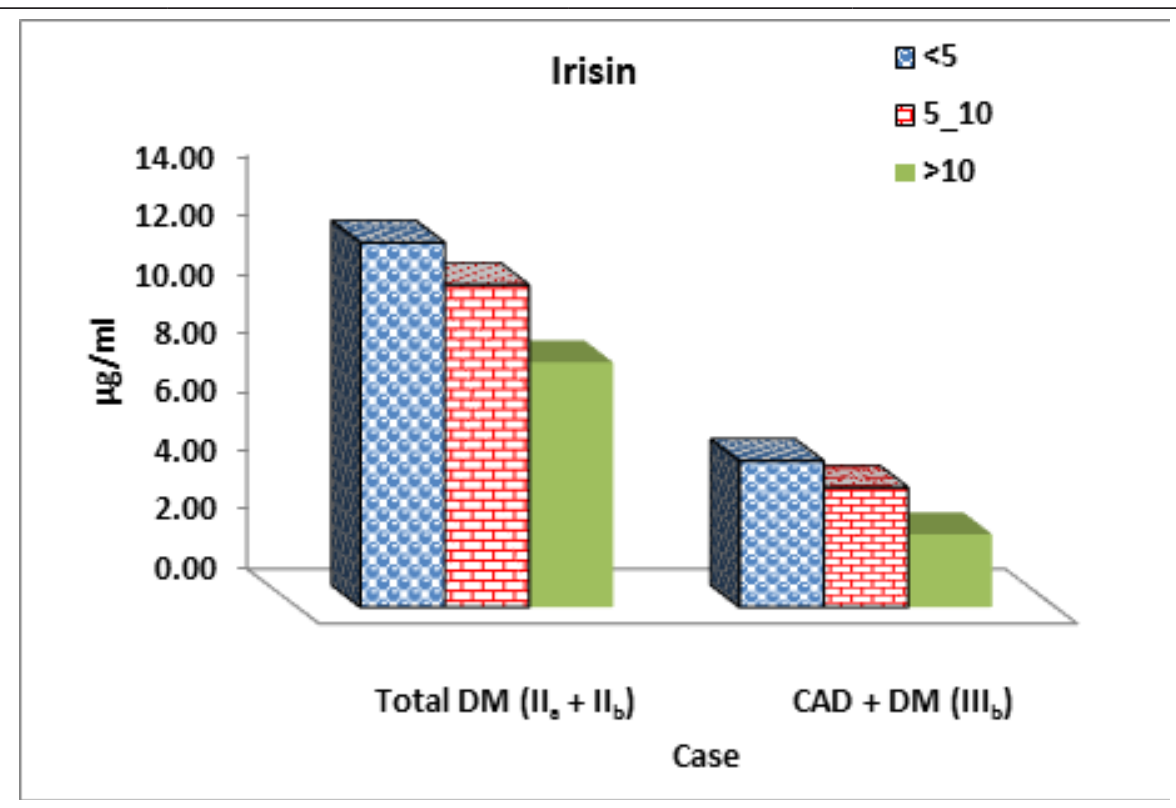

Figure (2): Bar chart showing the difference in means between serum Irisin level and duration of T2DM in total DM and in CAD + DM group

There was a significant increase in means of FPG and $\mathrm{HbAlc}$ for overall groups when compared with that

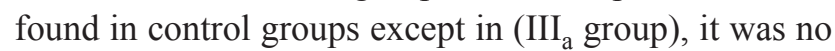
significant difference. The results showed no significant difference in mean of FPG and HbAlc levels [between control groups $\left(\mathrm{I}_{\mathrm{a}}\right.$ and $\left.\mathrm{I}_{\mathrm{b}}\right)$, between diabetic groups $\left(\mathrm{II}_{\mathrm{a}}\right.$ and $\left.\mathrm{II}_{\mathrm{b}}\right)$, and among groups $\left.\left(\mathrm{II}_{\mathrm{a}}, \mathrm{II}_{\mathrm{b}}, \mathrm{III}_{\mathrm{b}}\right)\right]$, table (4). 
Table (4): The mean serum level of fasting plasma glucose and HbA1c

\begin{tabular}{|c|c|c|}
\hline $\begin{array}{l}\text { Parameters } \\
\text { Groups }\end{array}$ & $\begin{array}{l}\text { FPG } \\
(\text { mean } \pm \mathrm{SD})\end{array}$ & $\begin{array}{l}\text { HbAlc } \\
(\text { mean } \pm \text { SD) }\end{array}$ \\
\hline $\mathrm{I}_{\mathrm{a}}$ & $\begin{array}{l}\text { A } \\
94.68 \pm 6.99\end{array}$ & $\begin{array}{l}\text { A } \\
5.146 \pm 0.453\end{array}$ \\
\hline $\mathrm{I}_{\mathrm{b}}$ & $\begin{array}{l}\text { A } \\
95.08 \pm 6.37\end{array}$ & $\begin{array}{l}\text { A } \\
5.392 \pm 0.526 \\
\end{array}$ \\
\hline $\mathrm{II}_{\mathrm{a}}$ & $\begin{array}{l}\text { B } \\
215.13 \pm 79.85\end{array}$ & $\begin{array}{l}\text { B } \\
8.497 \pm 2.015\end{array}$ \\
\hline $\mathrm{II}_{\mathrm{b}}$ & $\begin{array}{l}\text { B } \\
214.24 \pm 85.59 \\
\end{array}$ & $\begin{array}{l}\text { B } \\
8.360 \pm 2.324 \\
\end{array}$ \\
\hline $\mathrm{III}_{\mathrm{a}}$ & $\begin{array}{l}\mathbf{A} \\
95.10 \pm 5.73\end{array}$ & $\begin{array}{l}\text { A } \\
5.125 \pm 0.343\end{array}$ \\
\hline $\mathrm{III}_{\mathrm{b}}$ & $\begin{array}{l}\text { B } \\
229.76 \pm 99.44\end{array}$ & $\begin{array}{l}\mathbf{B} \\
8.615 \pm 1.528\end{array}$ \\
\hline LSD & 52.649 & 1.170 \\
\hline $\mathrm{P}$-value & Sig. 0.00027 & Sig.0.00014 \\
\hline
\end{tabular}

There was a significant increase in means of serum cholesterol and triglyceride for overall groups when compared with that found in control groups except in (III ${ }_{\text {a }}$ group), it was no significant difference. The results showed no significant difference in mean of cholesterol and triglyceride levels [between control groups ( $\mathrm{I}_{\mathrm{a}}$ and $\mathrm{I}_{\mathrm{b}}$ ), between diabetic groups $\left(\mathrm{II}_{\mathrm{a}}\right.$ and $\mathrm{II}_{\mathrm{b}}$ ), and among groups $\left.\left(\mathrm{II}_{\mathrm{a}}, \mathrm{II}_{\mathrm{b}}, \mathrm{III}_{\mathrm{b}}\right)\right]$.

Table (5): The mean serum level of lipid profile

\begin{tabular}{|c|c|c|c|c|c|}
\hline $\begin{array}{l}\text { Parameters } \\
\text { Groups }\end{array}$ & $\begin{array}{l}\text { Cholesterol (mg/dl) } \\
) \text { mean } \pm \text { SD)) }\end{array}$ & $\begin{array}{l}\text { TG }(\mathrm{mg} / \mathrm{dl}) \\
(\operatorname{mean} \pm \mathrm{SD})\end{array}$ & $\begin{array}{l}\begin{array}{l}\text { HDL-C } \\
(\mathrm{mg} / \mathrm{dl})\end{array} \\
(\mathrm{mean} \pm \\
\text { SD) }\end{array}$ & $\begin{array}{l}\text { LDL-C }(\mathrm{mg} / \mathrm{dl}) \\
(\text { mean } \pm \text { SD })\end{array}$ & $\begin{array}{l}\text { VLDL-C }(\mathrm{mg} / \\
\text { dl) } \\
(\text { mean } \pm \mathrm{SD})\end{array}$ \\
\hline Ia & $\begin{array}{l}\text { A } \\
99.07 \pm 23.37\end{array}$ & $\begin{array}{l}\text { A } \\
151.93 \pm 29.13\end{array}$ & $\begin{array}{l}\text { A } \\
46.143 \pm \\
6.559 \\
\end{array}$ & $\begin{array}{l}\text { A } \\
85.93 \pm 32.42\end{array}$ & $\begin{array}{l}\text { A } \\
19.857 \pm 4.625\end{array}$ \\
\hline $\mathrm{Ib}$ & $\begin{array}{l}\text { A } \\
94.16 \pm 35.60\end{array}$ & $\begin{array}{l}\text { A } \\
152.72 \pm 28.98\end{array}$ & $\begin{array}{l}\text { A } \\
46.920 \pm \\
12.926\end{array}$ & $\begin{array}{l}\text { A } \\
85.68 \pm 26.08\end{array}$ & $\begin{array}{l}\text { A } \\
18.880 \pm 7.114\end{array}$ \\
\hline IIa & $\begin{array}{l}\text { B } \\
173.20 \pm 28.54\end{array}$ & $\begin{array}{l}\text { B } \\
210.70 \pm 36.07\end{array}$ & $\begin{array}{l}\mathrm{B} \\
35.667 \pm \\
9.319\end{array}$ & $\begin{array}{l}\text { B } \\
141.10 \pm 41.23\end{array}$ & $\begin{array}{l}\text { B } \\
34.667 \pm 5.809\end{array}$ \\
\hline $\mathrm{IIb}$ & $\begin{array}{l}\text { B } \\
174.16 \pm 66.11\end{array}$ & $\begin{array}{l}\text { B } \\
212.96 \pm 48.19\end{array}$ & $\begin{array}{l}\text { B } \\
37.680 \pm \\
9.728\end{array}$ & $\begin{array}{l}\text { B } \\
136.92 \pm 45.42\end{array}$ & $\begin{array}{l}\text { B } \\
34.920 \pm 13.260\end{array}$ \\
\hline IIIa & $\begin{array}{l}\text { A } \\
128.95 \pm 29.68\end{array}$ & $\begin{array}{l}\text { B } \\
237.20 \pm 35.96\end{array}$ & $\begin{array}{l}\text { C } \\
28.200 \pm \\
9.950\end{array}$ & $\begin{array}{l}\mathrm{C} \\
182.90 \pm 39.81\end{array}$ & $\begin{array}{l}\mathrm{C} \\
25.750 \pm 5.946\end{array}$ \\
\hline
\end{tabular}

There were a significant decrease in means serum levels of HDL-C for overall groups when compared with that found in control groups. While there was a significant increase in means of serum LDL-C and VLDL-C for overall groups when compared with that found in control groups. The results showed no significant difference in mean of HDL-C, LDL-C and VLDL-C levels [between control groups $\left(\mathrm{I}_{\mathrm{a}}\right.$ and $\left.\mathrm{I}_{\mathrm{b}}\right)$, between diabetic groups ( $\mathrm{II}_{\mathrm{a}}$ and $\left.\mathrm{II}_{\mathrm{b}}\right)$, and among groups $\left.\left(\mathrm{II}_{\mathrm{a}}, \mathrm{II}_{\mathrm{b}}, \mathrm{III}_{\mathrm{b}}\right)\right]$, table (5). 
Cont... Table (5): The mean serum level of lipid profile

\begin{tabular}{|c|c|c|c|c|c|}
\hline IIIb & $\begin{array}{l}\text { B } \\
168.61 \pm 66.73\end{array}$ & $\begin{array}{l}\text { B } \\
238.64 \pm 46.73\end{array}$ & $\begin{array}{l}\mathrm{C} \\
22.606 \pm \\
6.113\end{array}$ & $\begin{array}{l}\text { C } \\
179.12 \pm 55.57\end{array}$ & $\begin{array}{l}\text { B } \\
33.758 \pm 13.339\end{array}$ \\
\hline LSD & 36.840 & 30.683 & 7.289 & 33.328 & 7.380 \\
\hline P-value & Sig.0.00011 & Sig.0.00011 & Sig. 0.00009 & Sig. 0.00017 & Sig. 0.00024 \\
\hline
\end{tabular}

\section{Discussion}

There was a significant decrease in mean serum level of Irisin for $\left(\mathrm{II}_{\mathrm{a}}, \mathrm{II}_{\mathrm{b}}, \mathrm{III}_{\mathrm{a}}, \mathrm{III}_{\mathrm{b}}\right)$ as compared with that found in $\left(\mathrm{I}_{\mathrm{a}}, \mathrm{I}_{\mathrm{b}}\right)$ groups. Also, when compared the serum levels of Irisin between DM subgroups with and without CAD showed that Irisin decreased when CAD existed but did not reach the significant level (maybe due to small sample size) as shown in the table (2), figure (1).

A study performed by Zhang et al. supports the current study the authors found a significant decrease in serum Irisin in T2DM, which further confirmed the potential role of Irisin in glucose metabolism and diabetes. Additionally, when compared the serum levels of Irisin between diabetic patients with and without macrovascular disease, they had found that Irisin significantly decreased when macrovascular disease existed. So they suggested that Irisin would be a potential target for monitoring and intervention of T2DM and its associated vascular complications such as CAD ${ }^{(\mathbf{8})}$. Besides, the founding of the current study resembles those found by El-Lebedy et al., who reported that serum Irisin was significantly lower in diabetic patients and CVD as compared to the control group. Also, Deng reported that serum Irisin level was lower significantly in patients with CAD as compared with healthy controls (9).

The above results were in agreement with more recent results, by Khorasani et al., who found that serum Irisin level was lower in diabetic patients with cardiovascular complication compared with uncomplicated diabetic patients ${ }^{(10)}$.

Studies that have been done to compare the levels of circulating Irisin with the healthy control group have shown a protective effect of Irisin against the development of CVD. Several potential mechanisms have been proposed for this issue. Irisin plays a vital role in the preservation of endothelial cell function and reduces endothelial damage by inhibiting inflammation, and oxidative stress, so the low levels of Irisin affect the endothelial function and increase the incidence of atherosclerosis. Besides lower circulating, Irisin levels can increase the accumulation of advanced glycation endproducts (one of the causes of vascular complications in diabetic patients) ${ }^{(11)}$.

The data and the results in this research did not show any significant difference between the two DM groups $\left(\mathrm{II}_{\mathrm{a}}, \mathrm{II}_{\mathrm{b}}\right)$ for all measured parameters in this study. Therefore, they can be merged and deal with as a single group (total DM) as shown in table (3), figure (2).

The present study showed a significant inverse relationship between serum Irisin and the duration of incidence of T2DM in the [total DM group $\left.\left(\mathrm{II}_{\mathrm{a}}+\mathrm{II}_{\mathrm{b}}\right)\right]$ and the $\left[\mathrm{CAD}+\mathrm{DM}\right.$ group $\left.\left(\mathrm{III}_{\mathrm{b}}\right)\right]$, Irsin decreases significantly as the period of diabetes increases as shown in table (3), figure (2).

These results resemble the finding of Liu et al., who pointed out that long-term diabetes is associated with a significant reduction in levels of Irisin ${ }^{(12)}$. Also, the results confirmed those found by two previous studies in which there was a negative correlation between duration of diabetes and Irisin level ${ }^{(\mathbf{1 3})}$.

\section{Conclusion}

The serum level of Irisin is affected inversely by the persistence of diabetes with or without coronary artery disease for an extended period, and the level of decline is significant decrease with an increase in the period of diabetes. Therefore it can be used as a prognostic marker for estimation of the severity of the T2DM.

Ethical Clearance: The Research Ethical Committee at scientific research by ethical approval of both environmental and health and higher education and 
scientific research ministries in Iraq

Conflict of Interest: The authors declare that they have no conflict of interest.

Funding: Self-funding

\section{References}

1. Milanesi A, Weinreb JE. Diabetes in the Elderly. Endotext comprehensive Endocrinology book. 2017.

2. Chawla A, Chawla R, Jaggi S. Microvascular and macrovascular complications in diabetes mellitus: Distinct or continuum?. Indian J Endocrinol Metab. 2016; 20(4): 546-551.

3. Novelle MG, Contreras C, Romero-Picó A, López M, Diéguez C. Irisin, Two Years Later. Inter J Endocrinol. 2013.

4. Esfahani M, Baranchi M, Mohammad Godarzi MT. Irisin and Metabolic Disorder. Avicenna J Med Biochem. 2016; 4(1): e33230.

5. Jeremic N, Chaturvedi P, Tyagi SC. Browning of White Fat: Novel Insight Into Factors, Mechanisms, and Therapeutics. J Cell Physiol. 2017; 232(1): 6168.

6. Perakakis N, Triantafyllou GA, Fernández-Real JM, Huh JY, Park KH, Seufert J, Mantzoros CS. Physiology and role of irisin in glucose homeostasis. Nat Rev Endocrinol. 2017; 13 (6): 324-337.

7. Zhu Li, Gang W, Yan-juan Zhu, Chen-guang Li, Yun-Zhao Tang, Zhen-huan Jiang' "et al." The relationship between circulating Irisin levels and tissues AGE accumulation in type 2 diabetes patients. Biosci Rep. 2017; 37 (3).

8. Zhang M, Chen P, Chen S, Sun Q, Zeng QC, Chen JY "et al." The association of new inflammatory markers with type 2 diabetes mellitus and macrovascular complications: complications:a preliminary study. Eur Rev Med Pharmacol Sci. 2014; 18 (11):1567- 1572.

9. El- Lebedy DH, Ibrahim AA, Ashmawy IO. Novel adipokines vaspin and Irisin as risk biomarkers for cardiovascular diseases in type 2 diabetes mellitus. Diabetes Metab Syndr. 2018; 12 (5): 643-648.

10. Khorasani ZM, Bagheri RK, Yaghoubi MA, Chobkar S, Aghaee MA, Abbaszadegan MR, Sahebkar A. The association between serum Irisin level and cardiovascular disease in diabetic patients. Diabetes Metab Syndr. 2019; 13 (1): 786- 790.

11. Martinez Munoz IY, Camarillo Romero EDS, Garduno Garcia JJ. Irisin a Novel Metabolic Biomarker: Present Knowledge and Future Directions. Int J Endocrinol. 2018.

12. Liu JJ, Wong MD, Toy WC, Tan CS, Liu S, Ng XW 'et al.' Lower circulating Irisin is associated with type 2 diabetes mellitus. J Diabetes complications. 2013; 27 (4): 365- 369.

13. Shelbaya S, Abu Shady MM, Nasr MS, Bekhet MM, Mageed YA, Abbas M. Study of Irisin Hormone Level in Type 2 Diabetic Patients and Patients with Diabetic Nephropathy. Curr Diabetes Rev. 2018; 14(5):481-486. 